ORIGINAL PROF-2145

\title{
CHRONIC VIRAL HEPATITIS C INFECTION;
}

Frequency of impaired glucose tolerance in patients

Dr. Muhammad Sohail Anjum, Dr. Shahid Maqbool, Dr. Muhammad Hamid Saeed, Dr. Tanveer Hussain, Dr. Naila Kalsoom

ABSTRACT... Objective: The objective of the study was to measure the frequency of impaired glucose tolerance (IGT) in patients having chronic hepatitis $C$ at medical outpatient department (OPD) of Allied hospital Faisalabad. Sample technique: Non probability consecutive sampling. Duration of study: Duration of study was 6 months with first patient enrolled on 3.02.2010 and last patient enrolled on 07-082010. Setting: Medical (OPD) Outpatient Department of Allied Hospital, Faisalabad. Subjects: 375 patients with chronic hepatitis C, coming in Medical OPD of Allied hospital Faisalabad were enrolled. Methods: 375 patients diagnosed as having chronic hepatitis $C$ coming in Medical OPD of Allied hospital Faisalabad, were included in the study. Fasting and two hours after glucose load blood sample were collected in sterilized syringes and was tested for fasting blood glucose (FBS) and random blood glucose level (RBS). Results: In this study 375 patients having HCV positive on Elisa were enrolled. Out of 375 patients with chronic hepatitis C, $143(38.1 \%)$ were found to have IGT while $232(61.9 \%)$ were having no IGT. There was significant association between chronic hepatitis $\mathrm{C}$ and development of IGT. Conclusions: It is concluded that there is close association in the development of IGT in patients with chronic hepatitis C.

Key words: Chronic hepatitis C, Type 2 Diabetes mellitus, insulin resistance.

Article Citation

Anjum MS, Maqbool S, Saeed MH, Hussain T, Kalsoom N. Chronic Viral Hepatitis C Infection; Frequency of impaired glucose tolerance in patients. Professional Med J 2013;20(3): 374-380.

\section{INTRODUCTION}

Impaired glucose tolerance (IGT) is defined as "fasting plasma glucose level between $101 \mathrm{mg} / \mathrm{dl}$ - $126 \mathrm{mg} / \mathrm{dl}$ and plasma glucose levels between $140-200 \mathrm{mg}$ after 2 hours of 75 gram of oral glucose load"1. There are at least three hundred million people with IGT world wide ${ }^{2}$. Individuals with IGT are at $40 \%$ increased risk for developing type-2 diabetes mellitus over next five years ${ }^{3}$. It is also a risk factor for increased mortality and cardiovascular diseases ${ }^{4,5}$. IGT is categorized as a stage in the natural history of disordered carbohydrate metabolism and referred to a metabolic state intermediate between euglycemia and diabetes ${ }^{4,6}$. There is evidence that intensive life style changes in individuals with IGT prevented the development of type 2 diabetes mellitus by $58 \%$ and also reduced the morbidity and mortality due to cardiovascular pathology ${ }^{3}$. Oral glucose tolerance test (OGTT) is one of excellent tools recommended by WHO to identify persons with IGT ${ }^{6}$. OGTT might play an excellent roll in screening of persons infected with hepatitis $\mathrm{C}$ virus for $\mathrm{IGT}^{6}$. The prevalence of Hepatitis $\mathrm{C}$ virus in Pakistan is $8-10 \%$ and to treat hepatitis $C$ as per international recommendations cost approximately 4 lacs per patient $^{7}$. IGT is more common among patients suffering from chronic hepatitis $\mathrm{C}$ virus infection ${ }^{8,9}$. A comparative study done showed that prevalence of IGT was 30\% among patients suffering from chronic hepatitis C virus infection, while it was $14 \%$ in those who were not suffering from chronic hepatitis $C$ virus infection ${ }^{9}$. Another study showed that prevalence of IGT in chronic hepatitis $C$ virus infected patients is $42.28 \%{ }^{10}$. There is little local data available on this subject, thus this study will help to highlight the importance of screening of hepatitis $C$ virus infected patients for IGT. Thus this will help to decrease the morbidity and mortality associated with IGT in chronic hepatitis C patients.

\section{MATERIAL AND METHODS}

\section{Settings}

The study was conducted in the medical out patient department of Allied Hospital Faisalabad. Allied Hospital is a tertiary care teaching hospital having 1100 beds. 


\section{Duration}

The study was completed within 6 month after approval of synopsis. first patient was enrolled on 0302-2010 and last patient was enrolled on 07-08-2010.

\section{Sample Size}

Sample size was calculated by using WHO sample size calculator taking confidence level 95\%, population proportion 42.28\%,10 required precision .05. Sample size will be $n=375$

\section{Sample Technique}

By non probability consecutive sampling.

\section{Inclusion Criteria}

All patients of either sex of age more than 25 years of age who had confirmed hepatitis $C$ virus by ELISA technique at least 6 months back ware included in the study.

\section{Exclusion Criteria}

All patients who were known to have diabetes mellitus, pregnancy, patients taking drugs (diuretics, oral contraceptive pills, phenytoin and steroids), acute myocardial infraction. (History of chest pain, vomiting and sweating was taken to rule out this), any recent surgery within one month, acute infection and fever , obesity. (Body mass index of more than $25 \mathrm{~kg} / \mathrm{m} 2$ was taken as obese). Both dyslipidemia and hypertension were included in the study.

\section{Study Design}

Descriptive cross sectional study.

\section{Data Collection Procedure}

The patients were selected from Medical OPD. The purpose of the research was explained to each patient. Those, who gave an informed consent, was included in the study. 375 patients who were Hepatitis $C$ virus infected coming in medical out patients Department of Allied Hospital fulfilling the above mentioned inclusion criteria were included. The enrolled patients were instructed to take unrestricted carbohydrate diet for three days, to avoid smoking, coffee and heavy exercise. After 8 hours over night fast venous blood sample was taken, which was labeled as fasting blood sugar (FBS) and sent to pathology laboratory of Allied Hospital, Faisalabad. Then $75 \mathrm{gm}$ glucose in a glass of water was given to the patient to drink in less than five minutes. After 2 hours venous blood sample was taken, which was labeled as Random blood sugar (RBS) and sent to pathology laboratory of Allied Hospital, Faisalabad. Proforma had been developed to record the results.

\section{DATA ANALYSIS}

The data was analyzed by using SPSS-10. The Descriptive statistics were calculated. The quantitative variables of the study were age , BMI, fasting blood sugar (FBS) and Random blood sugar (RBS) level. These variables were presented as Mean $\pm S D$. The qualitative variables were gender and impaired glucose tolerance. These were presented as frequency and percentage.

\section{ESULTS}

In this study total 375 patients having chronic hepatitis $C$ were included. Minimum age of the pt. was 25 and maximum 55 with a mean and STD of 42.95 and7.05 respectively (table I). Out of total 375 patients, 187 (49.9\%) were males and 188 (50.1\%) were females .Among age distribution the study showed that out of total 375 patients 49 (13.1\%) patients were having age from 25 to 35 years. Majority of them were among 3655 years of age groups. 203 (54.1\%) were having age from 36-45 years and 123 patients (32.8\%) were having their ages between 46-55 years (Table II). Among 49 patients between 25-35 years of age 14 were having IGT + ve. Among 36-45 years 61 were having IGT + ve and among 46-55 years 68 patients were having IGT + ve. (GRAPH 1). In this study, out of 375 patients, minimum FBS was $66 \mathrm{mg} / \mathrm{dl}$ and maximum was $126 \mathrm{mg} / \mathrm{dl}$.Mean FBS was 95.06 and Std.Deviation was 18.10 (table I)).Among 375 
patients $143(38.1 \%)$ has FBS more than $100 \mathrm{mg} / \mathrm{dl}$ and $232(61.9 \%)$ has FBS less than $100 \mathrm{mg} / \mathrm{dl}$ (TABLE III). Minum RBS was $100 \mathrm{mg} / \mathrm{dl}$ and maximum was $198 \mathrm{mg} / \mathrm{dl}$ with .mean RBS was142.13and Std. Deviation was 22.68 (TABLE I) .143(38.1\%) has RBS more than $140 \mathrm{mg} / \mathrm{dl}$ and $232(61.9 \%)$ less than 140mg/dl (TABLE IV). Among $375,166(44.3 \%)$ were having BMl between 18-21.Among these 41 were having IGT +ve. 209(55.7\%) were having BMI between 22-25. Among these 102 were having IGT + ve.(TABLE V-VI).

\begin{tabular}{|l|c|c|c|c|c|}
\hline & N & Minimum & Maximum & Mean & Std. Deviation \\
\hline Age & 375 & 25 & 55 & 42.95 & 7.05 \\
\hline Body mass index & 375 & 18 & 25 & 21.53 & 1.55 \\
\hline Fasting blood sugar & 375 & 66 & 126 & 95.06 & 18.10 \\
\hline Random blood sugar & 375 & 100 & 198 & 142.13 & 22.68 \\
\hline Valid N (list wise) & 375 & \multicolumn{2}{|c|}{} & \\
& \multicolumn{7}{|c|}{ Table-I. Descriptive statistics } \\
\end{tabular}

\begin{tabular}{|c|c|c|c|c|c|}
\hline & & Frequency & Percent & Valid Percent & Cumulative Percent \\
\hline Valid & $25-35$ & 49 & 13.1 & 13.1 & 13.1 \\
\hline & $36-45$ & 203 & 54.1 & 54.1 & 67.2 \\
\hline & $46-55$ & 123 & 32.8 & 32.8 & 100.0 \\
\hline & Total & 375 & 100.0 & 100.0 & \\
\hline
\end{tabular}

Table-II. Distribution of patients by age

\begin{tabular}{|c|c|c|c|c|c|}
\hline & & Frequency & Percent & Valid Percent & Cumulative Percent \\
\hline Valid & for $<100$ & 232 & 61.9 & 61.9 & 61.9 \\
\hline & for $>100$ & 143 & 38.1 & 38.1 & 100.0 \\
\hline & Total & 375 & 100.0 & 100.0 & \\
\hline
\end{tabular}

\begin{tabular}{|c|c|c|c|c|c|}
\hline & & Frequency & Percent & Valid Percent & Cumulative Percent \\
\hline Valid & for $<140$ & 232 & 61.9 & 61.9 & 61.9 \\
\hline & for $>140$ & 143 & 38.1 & 38.1 & 100.0 \\
\hline & Total & 375 & 100.0 & 100.0 & \\
\multicolumn{2}{|r|}{ Table-IV. Random blood sugar of patients of chronic HCV } \\
\hline
\end{tabular}




\begin{tabular}{|l|c|c|c|c|c|}
\hline & & Frequency & Percent & Valid Percent & $\begin{array}{c}\text { Cumulative } \\
\text { Percent }\end{array}$ \\
\hline Valid & for 18-21 & 166 & 44.3 & 44.3 & 44.3 \\
\hline & for 22-25 & 209 & 55.7 & 55.7 & 100.0 \\
\hline & Total & 375 & 100.0 & 100.0 & \\
\hline
\end{tabular}

Table-V. Distribution of patients by body mass index

\begin{tabular}{|l|c|c|c|c|}
\hline & & \multicolumn{2}{|c|}{$\begin{array}{c}\text { Impaired glucose } \\
\text { tolerance }\end{array}$} & Total \\
\hline & & IGT -ve & IGT + ve & \\
\hline $\begin{array}{l}\text { Body mass } \\
\text { index }\end{array}$ & for 18-21 & 125 & 41 & 166 \\
\hline & for 22-25 & 107 & 102 & 209 \\
\hline Total & & 232 & 143 & 375 \\
\hline \multicolumn{1}{|c|}{ Table-VI. Distribution of patients of Impaired glucose } \\
tolerance by body mass index
\end{tabular}

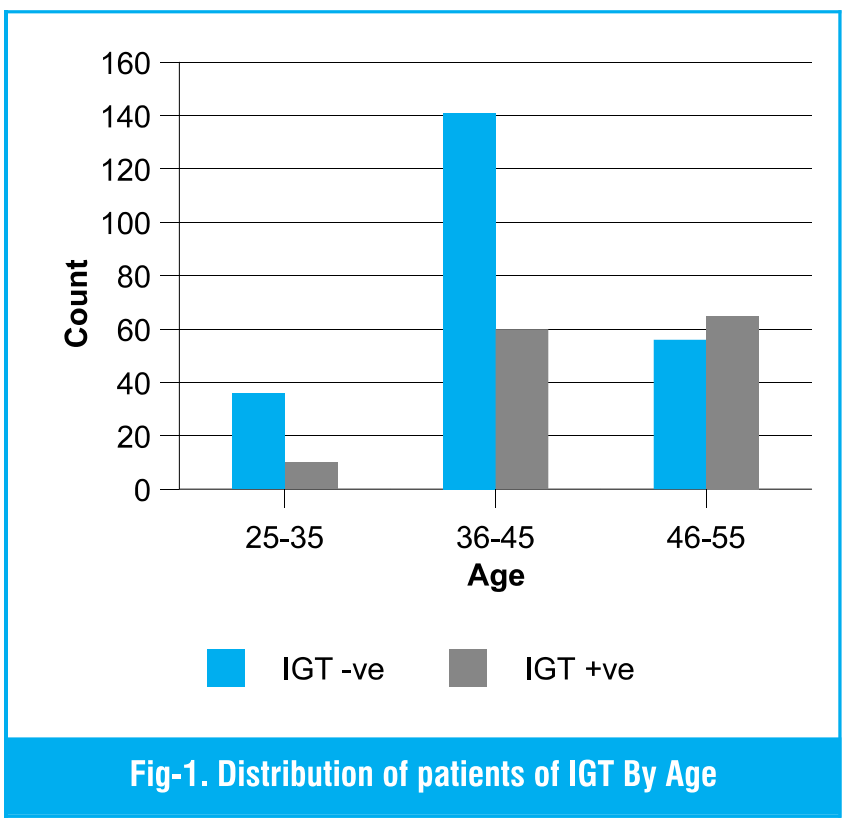

Out of 375 patients with CHC 143 (38.1\%) were found to have IGT while 232(61.9\%) were having no IGT. (Fig- 2). Most patients presented with IGT having age group 36-55. (Fig-1).

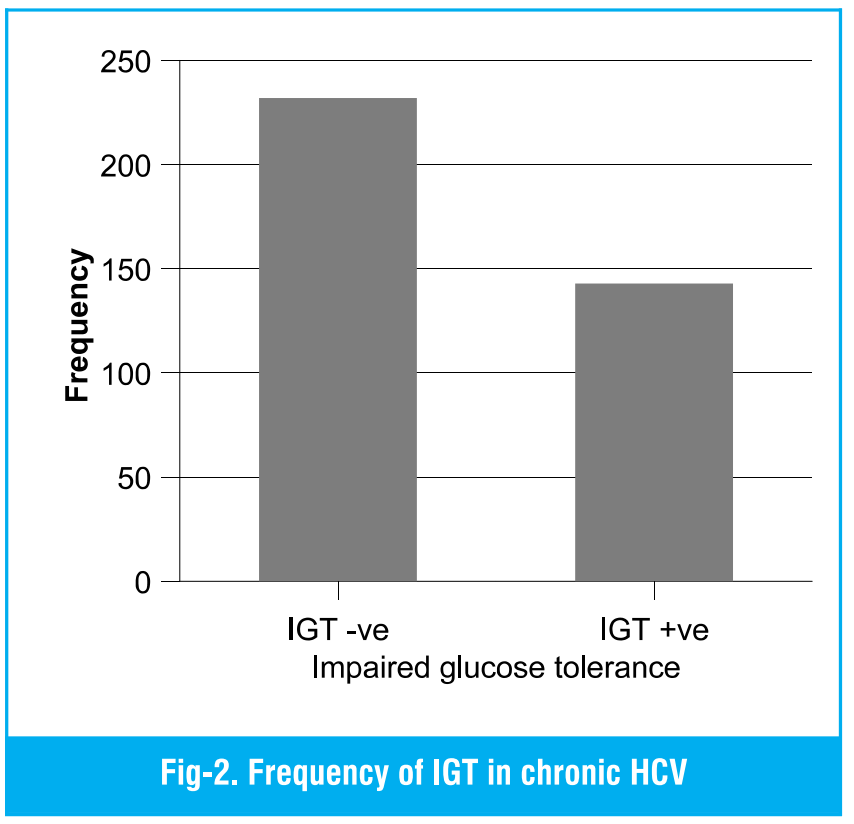

\section{DISCUSSION}

Hepatitis C virus (HCV) infects approximately 170 million individuals worldwide. Chronic HCV infection has been estimated to be responsible for approximately 250000 to 350000 deaths per year. Whereas the hepatic manifestations of hepatitis $C$ are well described the extrahepatic manifestations, though common, are less well appreciated. IGT is more common among patients suffering from chronic hepatitis $C$ virus infection ${ }^{11}$. There is well established relation between cirrhosis of liver and development of IGT and diabetes mellitus as its extra hepatic complication. Diabetes developed as a complication of cirrhosis is known as hepatogenous diabetes (HD). Around $30 \%$ to $60 \%$ of cirrhotic patients suffer from this metabolic disorder ${ }^{12}$. The first observation that 
cirrhotic patients infected with HCV may present with T2D ore often than patients with cirrhosis of other etiology was reported in 1994 by Allison et $\mathrm{al}^{13}$. In our study out of 375 patients with CHC, 143 (38.1\%) were found to have IGT while 232(61.9\%) were having no IGT. Out of total 375 patient's majority of them were among 36-55 years of age and. Slight male dominance was found in our patients. Khokhar $\mathrm{N}^{14}$ also reported the same pattern in a study conducted in Islamabad. An other study by Afzal M et al ${ }^{15}$ in 2004 showed that the levels of fasting blood glucose were towards the lower normal limit in patients having chronic hepatitis $\mathrm{C}$ while the levels of $\mathrm{HbA1c}$ were higher in patients having chronic hepatitis $C$. The glucose tolerance test showed a significant increase in the patients with IGT in Hepatitis C virus infection. Mehta SH et $\mathrm{a}^{16}$ in the United States, in a cross sectional study observed increased prevalence of type 2 diabetes and IGT occurs more often in persons with HCV infection who are older than 40 years of age. Suliman $\mathrm{Ml}$ et $\mathrm{al}^{17}$ in 2004 conducted a Comparative study a to establish a potential relationship between chronic hepatitis $C$ virus infection and diabetes mellitus in Bahawalpur. This study is comparable to our study. Ryu JK et al ${ }^{18}$ and Shah IA etal10 found highly significant association between IGT and HCV was found. P-.01. The incidence of type II DM and IGT among HCV infected patients with chronic disease has been reported variously from $23 \%$ to $62 \%{ }^{19}$. A recent, large meta-analysis, the first of this kind, has reached the same conclusion ${ }^{20}$. Insulin resistence and T2DM have important effects on the hepatitis C progression and response to antiviral therapy $^{21}$, which warrants specific and effective measures to correct such metabolic anomalies. The control of glucose abnormalities in CHC not only improves response to anti viral therapy but also decrease incidence of hepatocellular carcinoma ${ }^{22}$. However, as hyperglycemia and diabetes are independent risk factors for the response to treatment in patients with chronic HCV infection, early diagnosis and control of DM in these patients could result in better care and outcome of HCV patients. So, early screening of patients with chronic HCV infection for detection of IGT and glucose metabolism disorders is recommended to improve patients' outcome although better control of HCV could prevent development of IGT and DM in these patients.

\section{CONCLUSIONS}

Considering the disease burden and high economic cost of chronic hepatitis $C$ treatment, early detection of D.M will not only reduce the cost of treatment failure but will also help in identifying the patients who require early management of type 2 diabetes mellitus. The specific mechanisms by which HCV leads to IGT and type 2 diabetes are not fully understood, but it seems that an increase of insulin resistance associated with both steatosis and the overproduction of proinflammatory cytokines could play a crucial role. These mechanisms are initiated in the early stages of hepatic disease. The knowledge of the pathogenic mechanisms involved in IGT and diabetes associated with HCV infection will enable us not only to further identify those patients at high risk of developing diabetes but also to select the best therapeutic option and decrease the burden of complications related to $\mathrm{CHC}$ and hepatogenous Diabetes Mellitus.

\section{Copyright $@ 27$ Jan, 2013.}

\section{REFERENCES}

1. Power AC. Diabetes Mellitis In; Kasper DL, FauciAS, Longo DL, Braunwald E, Hauser LA, Jamson JL, (edi). Harrisons's principles of internal medicine vol II. 17th ed.New York: Magraw Hill 2008;2275-34.

2. Zimmet P. Epidemiology of diabetes mellitus and associated cardiovascular risk factors: Focus on human immunodeficiency virus and psychiatric disorders. Am J Med 2005;118:3-8.

3. Frier MB,Fisher M. Diabetes mellitus. In: Boon NA, Rcolledge NR, Walker BR ,. Hunter JAA, (edi). Davidson's principles and practices of medicine. 20th edi. Edinburgh:Churchill Livingston,2009: 805-49.

4. Impaired fasting glucose and impaired glucose tolerance: implications for care. Diabetes Care 
2007;30:753-59.

5. Bar EL, Zimmet PZ, Welborn TA, "Risk of cardiovascular and all-cause mortality in individuals with diabetes mellitus, impaired fasting glucose, and impaired glucose tolerance: the Australian Diabetes Obesity, and Lifestyle Study(AubDiab)". Circulation 2007; 116:151-7.

6. Lecube A, ,Hernandez C, Genesea J, Simo R, Glucose abnormalities in patients with Hepatitis C virus infection. Diabetes Care 200629 :1140-9.

7. Riaz-Ul-Hasan R, Epidemiology and clinical prevalence of HCV infection and diabetes mellitis, [thesis], Rawalpindi Department of BioChemistry University of Arid Agriculture 2008.

8. Ali SS, Ali IS, Amir AH, Jadoon Z, lanayatullah S. Frequency of hepatitis $\mathbf{C}$ infection in diabetic patients. J Ayub Med Coll Abbotabad, 2007;19:46-9.

9. Howard A, AA, Lo Y, Floris-Moore, M, Klein RS, Fleischer N, Schoenbaum EE,. Hepatitis C Virus Infection is associated with insulin resistance among older adults with or at risk of HIV infection. AIDS 2007;21:633-41

10. Shah IA, shah S,Hyat Z,Haq N,Noor M , and Arshad M. Impaired glucose tolerance in hcv/hbv 144. Strauss E. The importance of bacterial infections as precipating factors of chronic hepatic encephalopathy in cirrhosis. Hepatogastroenterology 1998; 45:900-4.

11. Mahmood K, Muhammad N, Ziauddin, Jan A. Frequency of hepatitis $B$ and $C$ viral markers in patients of cirrhosis liver in the North West Frontier Province. J Postgrad Med Inst 2008;22:140-3.

12. García-Compean D, Jaquez-Quintana J0, MaldonadoGarza H. Hepatogenous diabetes. Current views of an ancient problem. Ann Hepatol. 2009 ;8:13-20.

13. Allison ME, Wreghitt T, Palmer CR, Alexander GJ. Evidence for a link between hepatitis $C$ virus infection and diabetes mellitus in a cirrhotic population. $J$ Hepatol 1994; 21:1135-9

14. Khokhar N. Association of chronic hepatitis C virus infection and diabetes mellitus. Pak $\mathrm{J}$ Med Res 2002;41:155-8.

15. Afzal M, Mughal IA, Afzal N, Bashir MB, Malik FA. Chronic Hepatitis C infection; correlation of glucose tolerance test, the levels of fasting blood sugar (FBS) and Hemoglobin A1c (HbA1c). Professional Med $\mathrm{J}$ 2004;11:222-7.

16. Mehta SH, Brancati FL, Strathdee SA. Hepatitis C virus infection and incident type 2 Diabetes. Hepatology 2003; 38:50-6.

17. Suliman MI, Imran F, Irfan S. Relationship between chronic hepatitis C and type-2 diabetes mellitus in Bhawalpurian patients. Professional Med J 2004; 11:315-9.

18. Ryu JK, Lee SB, Hong SJ Lee S. Association of chronic hepatitis $C$ virus infection and diabetes mellitus in Korean patients. Korean J Intern Med. 2001; 16:18-23.

19. Caronia S, Taylor K, Pagliaro L, et al. Further evidence for an association between non-insulin-dependent diabetes mellitus and chronic hepatitis C virus infection. Hepatology. 1999;30:1059-63.

20. Wang CS, Wang ST, Yao WJ, Chang TT, Chou P. Hepatitis C virus infection and the development of type 2 diabetes in a community-based longitudinal study. Am J Epidemiol 2007;166: 196-203.

21. White DL, Ratziu V, El-Serag HB. Hepatitis C infection and risk of diabetes: a systematic review and metaanalysis. J Hepatol 2008; 49: 831-44

22. Veldt BJ, Chen W, Heathcote EJ, Wedemeyer H, Reichen J, Hofmann WP, et al. Increasedrisk of hepatocellular carcinoma among patients with hepatitis $\mathbf{C}$ cirrhosis and diabetes mellitus. Hepatology 2008; 47:185662. 


\section{AUTHOR(S):}

1. DR. MUHAMMAD SOHAIL ANJUM

M.B.B.S, MRCP (UK), MRCP (LONDON),

FCPS (Medicine)

Assistant Professor of Medicine

Independent Medical College, Faisalabad

2. DR. SHAHID MAQBOOL

MBBS,FCPS (Medicine)

Consultant Physician

Allied Hospital, Faisalabad

3. DR. MUHAMMAD HAMID SAEED

MBBS, FCPS (Medicine), FCPS (Cardiology)

Assistant Professor of Cardiology

Faisalabad Institute of Cardiology, Faisalabad.

4. Dr. Tanveer Hussain

M.B.B.S, FCPS (Med)

Consultant Physician

Govt. General Hospital, Samanabad, Faisalabad.
5. Dr. Naila Kalsoom

M.B.B.S

Medical Officer

National Hospital, Faisalabad.

Correspondence Address:

Dr. Muhammad Sohail Anjum

P-353, Street No.12, Taj Colony,

Sargodha Road, Behind MTM, Faisalabad

friendsohail712@gmail.com

\section{PREVIOUS RELATED STUDIES}

Dilshad Muhammad, Khalid Amin, Amin Anjum, Masood Javed. CHRONIC HEPATITIS C VIRUS INFECTION; ASSOCIATION WITH TYPE 2 DIABETES MELLITUS (Original) Prof Med Jour 17(4) 557-562 Oct, Nov, Dec 2010.

Muhammad Naeem, Ameer Ahmad, Imran Qaisar, Fiaz Ahmad. STATUS OF HEPATITIS C VIRUS (HCV) INFECTIONS; CHILDREN ADMITTED IN PEDIATRIC WARD OF BAHAWAL VICTORIA HOSPITAL BAHAWALPUR (Original) Prof Med Jour 18(3) 445-449 Jul, Aug, Sep 2011.

Muhammad Afzal, Irfan Ahmed Mughal, Naushen Afzal, Muhammad Badar Bashir, Fiyaz Ahmed Malik. CHRONIC HEPATITIS C INFECTION; CORRELATION OF GLUCOSE TOLERANCE TEST, THE LEVELS OF FASTING BLOOD SUGAR (FBS) AND HEMOGLOBIN (Original) Prof Med Jour 11(2) 222-227 Apr, May, Jun, 2004.



